\title{
EDUKASI KESEHATAN DI KELURAHAN TOMANG JAKARTA BARAT DALAM RANGKA PENCEGAHAN DAN PENGELOLAAN PENYAKIT TIDAK MENULAR
}

\author{
Yoanita Widjaja $^{1}$, Enny Irawaty $^{2}$, Rebekah Malik $^{3}$ \\ 1,2,3 Fakultas Kedokteran Universitas Tarumanagara, Jakarta \\ Email: yoanitaw@fk.untar.ac.id
}

\begin{abstract}
ABSTRAK
Beberapa penyakit tidak menular seperti diabetes melitus, stroke, penyakit jantung koroner termasuk 10 penyebab kematian tertinggi di Indonesia. Faktor risiko penyakit tersebut diantaranya yaitu hipertensi, dislipidemia, obesitas, merokok, dan inaktivitas fisik. Faktor risiko dapat dicegah dan diatasi dengan menjalani pola hidup sehat. Namun, masyarakat Indonesia khususnya warga Kelurahan Tomang kurang menyadari pentingnya hidup sehat. Oleh karena itu, kegiatan pengabdian kepada masyarakat ini bertujuan memberikan pelayanan kesehatan melalui edukasi pentingnya hidup sehat sehingga masyarakat termotivasi untuk mengimplementasikannya dalam kehidupan seharihari dan menularkannya pada keluarga serta masyarakat. Metode pelaksanaan, berupa pemeriksaan kesehatan bagi warga masyarakat, yaitu pemeriksaan antropometri, tekanan darah, pengecekan kadar gula darah, asam urat, dan kolesterol.Setelah mendapatkan hasil pemeriksaan, dilakukan edukasi/penyuluhan. Hasil kegiatan ini dari 83 peserta (warga), bahwa terbanyak (62.7\%) yang mengalami kelebihan berat badan atau obesitas, kemudian asam urat tinggi sebanyak $25,3 \%$ kolesterol tinggi sebanyak 16,9\%, peningkatan tekanan darah sebanyak 10,8\%, dan pengukuran kadar gula darah sewaktu tinggi sebanyak 4,8\%, Sетиa diberikan edukasi mengenai manfaat aktivitas fisik, diet seimbang, dan pemeriksaan kesehatan secara berkala untuk mencegah maupun mengatasi penyakit tidak menular terutama penyakit metabolik. Kesimpulan yang dapat dikemukakan bahwa edukasi ini memberikan pengetahuan, membuka wawasan, serta meningkatkan motivasi warga peserta mengenai pentingnya modifikasi pola hidup untuk mencegah timbulnya penyakit tidak menular, khususnya penyakit metabolik, dan komplikasinya. Kelebihan berat badan hingga obesitas merupakan faktor risiko terbanyak yang ditemukan. Berdasarkan hal tersebut, masalah kelebihan berat badan pada masyarakat dapat menjadi fokus kegiatan.
\end{abstract}

Kata kunci: Penyakit metabolik; Penyakit tidak menular; Edukasi; Kelurahan Tomang

\section{PENDAHULUAN}

Sehat adalah keadaan sejahtera fisik, mental, dan sosial secara utuh, tidak semata-mata bebas dari penyakit atau kecacatan. Seseorang tidak selalu berada dalam keadaan sehat, ada kalanya juga dalam keadaan sakit atau bahkan tidak mengetahui bahwa dirinya sedang sakit. Kelompok penyakit penyebab kematian yang penderitanya semakin meningkat saat ini, yaitu penyakit tidak menular (PTM). Menurut World Health Organizaion (WHO), saat ini PTM merupakan penyebab kematian dari 41 juta atau $71 \%$ orang di dunia setiap tahunnya. Setiap tahun, 15 juta orang meninggal di usia 30-69 tahun karena PTM, dan 85\% nya terjadi di negara dengan ekonomi rendah hingga menengah (WHO, 2018). Di Indonesia, PTM juga merupakan penyebab kematian terbanyak. Proporsi angka kematian akibat PTM di Indonesia semakin meningkat, yaitu 41,7\% pada tahun 1995, kemudian pada tahun 2001 bertambah menjadi 49,9\%, menjadi 59,5\% pada tahun 2007 (Kementerian Kesehatan Republik Indonesia, 2011). WHO memperkirakan angka ini akan terus meningkat di dunia (WHO, 2018).

Prevalensi PTM semakin meningkat di Indonesia. Hasil Riset Kesehatan Dasar (Riskesdas) tahun 2018 menunjukkan prevalensi PTM mengalami peningkatan dibandingkan hasil Riskesdas tahun 2013 , seperti hipertensi yang meningkat $8,3 \%$ menjadi $34,1 \%$, diabetes melitus meningkat $4 \%$ menjadi $10,9 \%$, stroke meningkat $3,9 \%$ menjadi $10,9 \%$, dan penyakit ginjal kronis meningkat 1,8\% menjadi 3,8\%o (Kementerian Kesehatan Republik Indonesia, 2018). Peningkatan prevalensi PTM tersebut berhubungan dengan gaya hidup dan pola makan. Faktor gaya hidup dan pola makan yang mempengaruhi timbulnya PTM yaitu konsumsi tembakau, garam, dan kurang aktivitas fisik. Faktor risiko PTM lainnya yang secara khusus dapat mempengaruhi timbulnya penyakit metabolik, yaitu peningkatan tekanan darah, berat badan berlebih hingga obesitas, hiperglikemia, 
dan hiperlipidemia (WHO, 2018). Di Indonesia, hasil Riskesdas tahun 2018 juga memperlihatkan peningkatan prevalensi atau proporsi beberapa faktor risiko PTM, seperti obesitas $21,8 \%$, obesitas sentral 31\%, konsumsi tembakau (33,8\%), konsumsi alkohol (3,3\%), kurang aktivitas fisik $(33,5 \%)$, dan kurang konsumsi buah atau sayur (95,5\%) (Kementerian Kesehatan Republik Indonesia, 2018).

Peningkatan prevalensi faktor risiko dan PTM mengindikasikan bahwa diperlukan adanya kegiatan yang menggerakkan dan memotivasi masyarakat untuk hidup sehat dan mengubah gaya hidup yang kurang baik. Salah satu upaya yang dilakukan pemerintah pada tahun 2016 yaitu dengan mencanangkan Gerakan Masyarakat Hidup Sehat atau Germas. Germas berfokus pada aktivitas fisik 30 menit per hari, konsumsi sayur dan buah, dan memeriksa kesehatan secara rutin. Ketiga fokus ini dilakukan untuk mewujudkan paradigma sehat dengan tujuan meningkatkan kesadaran, kemauan, dan kemampuan berperilaku hidup sehat. Pelaksanaan Germas dimulai dari keluarga, karena sikap seseorang dapat dibentuk dari keluarga (Kementerian Kesehatan Republik Indonesia, 2016).

Dalam rangka menyukseskan Germas, dibutuhkan adanya partisipasi dari segenap masyarakat, terutama institusi pendidikan yang diharapkan dapat mengedukasi masyarakat. Fakultas Kedokteran Universitas Tarumanagara (FK Untar) menunjukkan keikutsertaannya secara aktif untuk menyukseskan Germas dengan cara mengadakan kegiatan pengabdian masyarakat. FK Untar merupakan institusi pendidikan yang terletak di Kelurahan Tomang, Jakarta Barat. Hal ini menjadi salah satu alasan diselenggarakannya kegiatan pengabdian masyarakat di Kelurahan Tomang. Selain itu, Kelurahan Tomang juga merupakan daerah binaan Universitas Tarumanagara yang lokasinya terdapat di lingkungan FK Untar dan merupakan wilayah yang warganya sering diajak kerjasama, salah satunya untuk kepentingan pembelajaran yaitu sebagai pasien simulasi. Kelurahan ini memiliki luas wilayah $1.88 \mathrm{~km}^{2}$ ini, terdiri dari 8,841 kepala keluarga, $16 \mathrm{RW}$ dan 174 RT. Penduduk di kelurahan ini berjumlah 36.230 jiwa (17.639 perempuan dan 18.591 lakilaki) dan mayoritas beragama Islam $(47,18 \%)$. Mata pencaharian penduduk bervariasi seperti bidang industri, transportasi, keuangan, ABRI, PNS, jasa, perdagangan, guru dan dosen. Pada kelurahan Tomang ada satu puskesmas kelurahan yang terletak di wilayah RW 5.

Berdasarkan hasil wawancara dan data dari kepala puskesmas Tomang, diketahui bahwa banyak warga kelurahan Tomang yang menderita diabetes melitus. Diabetes melitus, yang merupakan salah satu penyakit metabolik, menempati urutan ke 8 dari 10 penyakit tersering di wilayah Kelurahan Tomang. Selain itu, ditemukan pula kurangnya pengetahuan masyarakat tentang diabetes melitus, pencegahannya serta pengaturan pola hidup yang sehat. Salah satu cara untuk mengantisipasi peningkatan jumlah kasus diabetes dan komplikasinya adalah dengan mengubah pola hidup masyarakat dengan cara edukasi. Edukasi ini merupakan suatu hal yang amat penting bagi penderita diabetes dalam upaya kontrol gula darahnya. Pengaturan jumlah dan jenis makanan serta olahraga yang baik dapat mencegah atau menghambat munculnya penyulit kronik maupun akut. Perubahan pola hidup yang dilakukan penderita dan keluarganya sangat mempengaruhi keberhasilan pengobatan diabetes sehingga harapan hidup penderita dapat meningkat (Soegondo 2002). Besarnya peran edukasi dalam upaya pencegahan PTM khususnya penyakit metabolik, dan komplikasinya, mendorong dilakukannya pengabdian masyarakat dalam bentuk pemberian edukasi bagi warga kelurahan Tomang. Kegiatan pengabdian masyarakat ini bertujuan untuk memberikan informasi bagi warga mengenai cara pencegahan PTM khususnya penyakit metabolik dan komplikasinya, sehingga warga peserta dapat menularkannya kepada keluarga dan masyarakat. 


\section{METODE PELAKSANAAN}

Luaran yang diharapkan dari kegiatan pengabdian kepada masyarakat (Abdimas) ini yaitu peningkatan wawasan/pengetahuan masyarakat di Kelurahan Tomang Jakarta Barat dalam bidang kesehatan yang terkait diabetes melitus, dislipidemia, hiperurisemia, hipertensi, dan obesitas serta manajemennya melalui pola hidup sehat. Selanjutnya diharapkan terjadi peningkatan status kesehatan serta berkurangnya angka kejadian PTM terutama penyakit metabolik pada masyarakat di Kelurahan Tomang.

Upaya yang dilakukan untuk mencapai luaran tersebut yaitu dengan menggunakan metode skrining, edukasi dan demonstrasi. Metode skrining dilakukan untuk menilai tekanan darah, berat badan, kadar gula darah, kadar kolesterol, dan asam urat. Metode edukasi dilakukan untuk memberikan pendidikan kesehatan pada kelompok risiko terkait isu PTM dan pencegahan komplikasinya, serta Germas. Metode demonstrasi dilakukan untuk memberikan contoh gerakan senam sebagai salah satu upaya gaya hidup sehat yang dapat mencegah PTM.

Persiapan kegiatan dimulai dengan mengadakan survei lapangan dan meminta ijin kepada Bapak Lurah Tomang serta pihak terkait. Selanjutnya, dengan kolaborasi bersama kader di Kelurahan Tomang, dilakukan pendataan warga calon peserta kegiatan untuk distribusi tiket pemeriksaan yang akan dibawa saat kegiatan. Saat hari pelaksanaan, warga yang datang diminta untuk melakukan registrasi ulang dengan menunjukkan tiket. Setelah itu, warga mengisi data identitas diri sambil menunggu panggilan di area tunggu untuk dilakukan skrining faktor risiko PTM, yang meliputi pengukuran tekanan darah, berat badan, tinggi badan, dan pemeriksaan darah dengan menggunakan alat pemeriksa kadar gula darah, kolesterol, dan asam urat mandiri. Setelah diperoleh hasil pemeriksaan, warga diberi edukasi yang sesuai oleh tim dokter.

Semua warga peserta diberikan penjelasan pentingnya menjaga pola makan dan gaya hidup sehat. Warga peserta yang terdeteksi memiliki faktor risiko atau yang sudah menderita penyakit metabolik diberikan edukasi mengenai penyakitnya dan penggunaan obat untuk mengontrol kondisinya untuk mencegah komplikasi. Warga peserta yang terdeteksi peningkatan tekanan darah ( $\geq 140 / 90 \mathrm{mmHg}$ ), dokter memberikan edukasi untuk mengurangi konsumsi garam yaitu $<2$ gram Natrium/hari atau setara dengan 1 sendok teh garam dapur. Makanan dengan kandungan tinggi natrium seperti makanan atau minuman kaleng, makanan yang diawetkan, bumbu penyedap, saus sambal, dan lain-lain, harus dihindari, konsumsi sayur dan buah-buahan segar, produk susu rendah lemak, gandum, ikan, dan asam lemak tak jenuh (terutama minyak zaitun), menurunkan berat badan dan menjaga berat badan ideal, serta olahraga teratur terutama latihan aerobik dinamik berintensitas sedang (seperti berjalan, joging, bersepeda, atau berenang) minimal 30 menit, yang dilakukan 5-7 hari/minggu dan berhenti merokok juga tidak mengonsumsi alkohol. (Indonesian Society of Hypertension, 2019)

Warga peserta yang terdeteksi memiliki kadar gula darah sewaktu tinggi ( $\geq 200 \mathrm{mg} / \mathrm{dl}$ ) diberikan edukasi mengenai penjelasan penyakit DM (perjalanan penyakit, komplikasi, tata laksana dan target terapi), penjelasan obat anti diabetikum (jenis obat, aturan pakai, efek samping, deteksi dan penanganan awal hipoglikemi) yang harus diminum teratur sesuai anjuran dokter dan dikonsumsi seumur hidup. Selain itu juga diberitahukan mengenai pengaturan asupan makan, yaitu makanan seimbang dengan komposisi karbohidrat 45-65\%, lemak 20-25\%, dan protein 10-20\% dari total kebutuhan kalori, konsumsi makanan berserat tinggi dan berprotein (sayur, buah, kacangkacangan, tahu, tempe, ikan, ayam tanpa kulit, dan produk susu rendah lemak) serta menghindari makanan yang mengandung lemak jenuh (daging berlemak atau susu full cream). Aktivitas fisik hendaknya dilakukan secara teratur sebanyak 3-5 kali/minggu selama 30-45 menit. Berat badan 
juga harus dijaga agar ideal. Perawatan kebersihan badan dan kaki juga merupakan hal penting, serta pemantauan gula darah secara mandiri atau pemeriksaan ke dokter secara rutin dan berkelanjutan. (Soelistijo SA et al, 2015)

Warga peserta yang terdeteksi memiliki kadar kolesterol tinggi (> $200 \mathrm{mg} / \mathrm{dL}$ ) diberikan edukasi mengenai konsumsi makanan yang dianjurkan yaitu sereal gandum, sayur, buah, kacangkacangan, ikan, susu atau yogurt skim. Cara pengolahan makanan yang disarankan yaitu memanggang, merebus, atau mengukus. Menggoreng makanan dengan banyak minyak sebaiknya dihindari. Jika berat badan berlebih, harus diturunkan hingga mencapai ideal dan melakukan aktivitas fisik 30 menit per hari selama 5 hari per minggu, serta menghentikan kebiasan merokok dan minum alkohol. (Erwinanto et al, 2017)

Warga peserta yang terdeteksi memiliki kadar asam urat darah tinggi (Laki-laki $>7 \mathrm{mg} / \mathrm{dL}$ dan perempuan $>6 \mathrm{mg} / \mathrm{dL}$ ) diberikan edukasi yang sama seperti penderita hipertensi, diabetes melitus, dan dislipidemia yaitu pengaturan pola makan, latihan fisik, dan menghentikan kebiasaan merokok. Pada pasien overweight atau obese, diberikan edukasi mengenai modifikasi pola makan agar mencapai berat badan ideal. Penderita dianjurkan menghindari makanan dan minuman tinggi purin seperti daging merah dan tinggi protein, kaldu, hati, ginjal, kerang, ekstrak ragi, alkohol. Hidrasi harus baik dengan minum air >2 liter per hari. Selain itu, latihan fisik yang berlebihan dan berisiko trauma sendi wajib dihindari. (Perhimpunan Reumatologi Indonesia, 2018)

Warga peserta yang memiliki berat badan berlebih hingga obesitas (IMT $\geq 23 \mathrm{~kg} / \mathrm{m}^{2}$ ) diberikan edukasi mengenai berbagai penyakit yang dapat terjadi akibat berat badan berlebih. Berat badan diturunkan secara bertahap dengan target penurunan $10 \%$ dari BB sekarang atau penurunan $1 / 2-1$ $\mathrm{kg}$ per minggu dengan perubahan pola makan dan aktivitas fisik. Pola makan yang dianjurkan porsi kecil namun sering dan mengurangi konsumsi lemak dan kalori. (Ikatan Dokter Indonesia, 2014)

\section{HASIL Dan PEMBAHASAN}

Kegiatan abdimas diselenggarakan di RPTRA Kelurahan Tomang, Jakarta Barat pada hari Minggu, 27 Januari 2019. Kegiatan dibuka oleh Bapak Lurah Tomang dengan melakukan pengguntingan pita. Peserta kegiatan yaitu sebanyak 83 orang. Jumlah ini lebih sedikit dari perkiraan, karena sebagian warga sedang bergotong royong membersihkan lingkungan di beberapa RW di Kelurahan Tomang yang beberapa hari sebelumnya mengalami musibah kebakaran. Alur kegiatan digambarkan dalam skema pada gambar 1.

Semua warga yang mengikuti kegiatan, diberikan edukasi mengenai pencegahan PTM khususnya penyakit metabolik secara umum mengenai penyakitnya dan penggunaan obat, serta program Germas, yaitu dengan melakukan aktivitas fisik, mengonsumsi makanan seimbang, dan pemeriksaan kesehatan secara berkala. Aktivitas fisik dilakukan setiap hari minimal 30 menit dan mengurangi kegiatan yang banyak duduk, seperti menonton TV, bermain gadget atau komputer. Makanan seimbang yang dianjurkan yaitu mengonsumsi sayur dan buah setiap hari, membatasi makanan yang mengandung gula, garam, minyak serta memperbanyak minum air putih. Pemeriksaan kesehatan yang dilakukan secara berkala meliputi pemeriksaan fisik (tekanan darah, berat badan, tinggi badan, lingkar perut, dada dan perut) serta pemeriksaan penunjang (darah lengkap, gula darah, kolesterol darah, asam urat). Warga peserta, yang terdeteksi dari hasil pemeriksaan, memiliki faktor risiko dan sudah menderita penyakit metabolik, secara khusus diberikan edukasi sesuai dengan materi yang sudah disiapkan untuk masing-masing penyakit. 


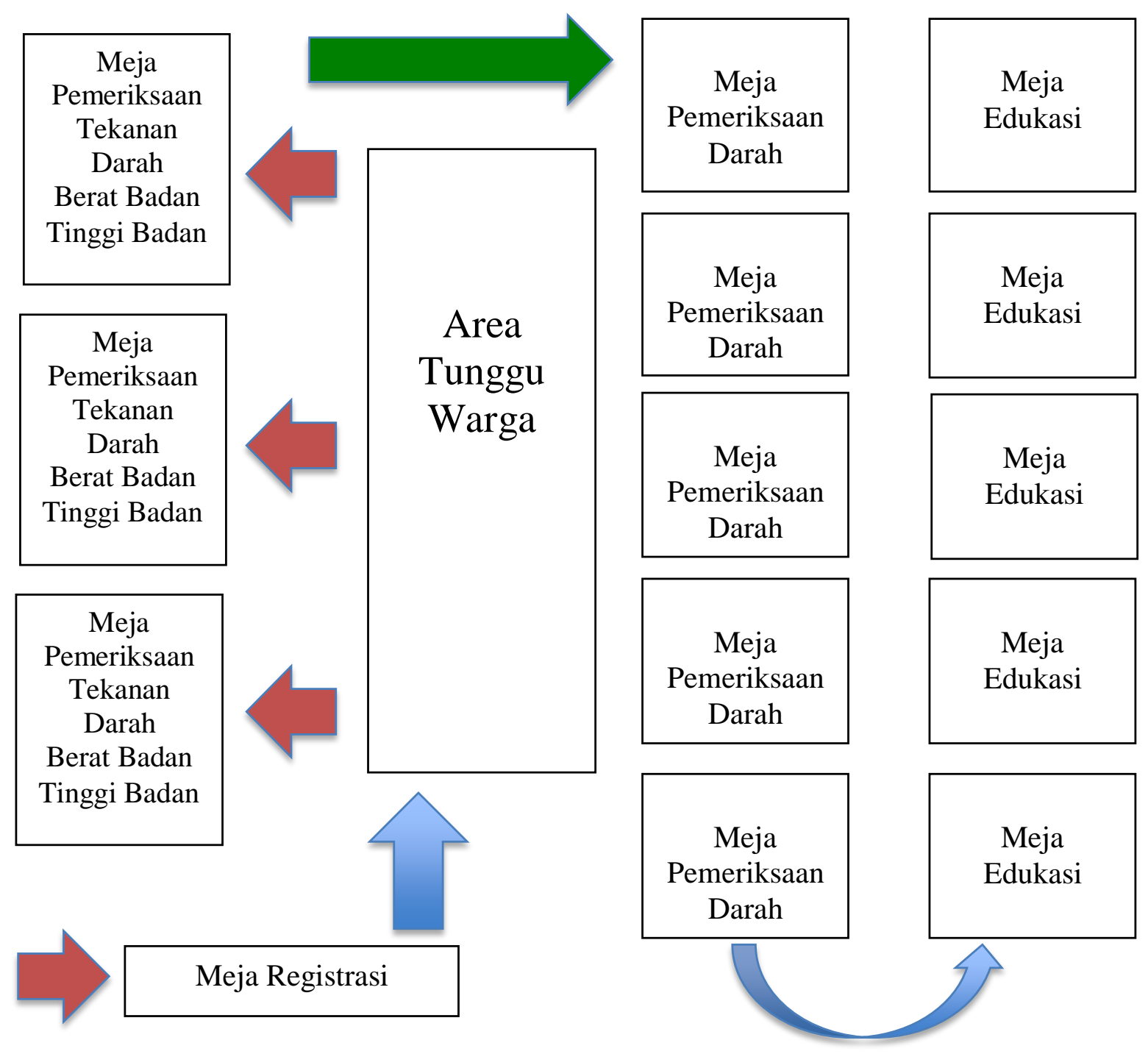

Gambar 1. Skema alur kegiatan

Pada kegiatan ini, lebih dari separuh peserta yang menghadiri kegiatan berjenis kelamin perempuan $(83,1 \%)$. Rentang usia warga peserta kegiatan ini yaitu dari 14 tahun hingga 78 tahun. Sebanyak $28,9 \%$ orang memiliki pendidikan terakhir minimal SMA.

Tabel 1. Karakteristik Warga Peserta Kegiatan

\begin{tabular}{clcc}
\hline No & \multicolumn{1}{c}{ Karakteristik } & $\mathbf{n = 8 3}$ & $\mathbf{\%}$ \\
\hline 1. & Jenis Kelamin & & \\
& Laki-laki & 14 & $16,9 \%$ \\
& Perempuan & 69 & $83,1 \%$ \\
2. & Usia (tahun) & & \\
& $<20$ & 2 & $2,4 \%$ \\
$21-30$ & 4 & $4,8 \%$ \\
$31-40$ & 12 & $14,5 \%$ \\
$41-50$ & 21 & $25,3 \%$ \\
& $51-60$ & 21 & $25,3 \%$ \\
\hline
\end{tabular}




\begin{tabular}{lcc}
\hline$>60$ & 23 & $27,7 \%$ \\
3. Tingkat Pendidikan & 21 & $25,3 \%$ \\
SD & 13 & $15,7 \%$ \\
SMP & 20 & $24,1 \%$ \\
SMA & 4 & $4,8 \%$ \\
Perguruan Tinggi & 25 & $30,1 \%$ \\
Tidak menjawab & \\
\hline
\end{tabular}

Dari hasil pemeriksaan yang dilakukan, warga yang mengalami peningkatan tekanan darah yaitu sebesar $10,8 \%$, peningkatan kadar gula darah sewaktu sebesar $4,8 \%$, peningkatan kadar kolesterol sebesar $16,9 \%$, peningkatan kadar asam urat sebesar 25,3\%, dan kelebihan berat badan hingga obesitas sebesar $62,7 \%$. Berdasarkan hasil pemeriksaan tersebut, berat badan berlebih dan obesitas merupakan masalah terbesar pada warga peserta kegiatan abdimas ini. Kelebihan berat badan dapat memicu timbulnya PTM, khususnya penyakit metabolik seperti hipertensi, diabetes melitus, dislipidemia, juga hiperurisemia.

Tabel 2. Hasil pemeriksaan

\begin{tabular}{|c|c|c|c|c|}
\hline \multirow{2}{*}{ No } & \multirow{2}{*}{ Pemeriksaan } & \multicolumn{2}{|c|}{ Hasil } & \multirow{2}{*}{ Nilai Rujukan } \\
\hline & & $\mathbf{n}$ & $(\%)$ & \\
\hline \multirow[t]{4}{*}{1.} & Tekanan Darah & & & \multirow{4}{*}{$\geq 140 / 90 \mathrm{mmHg}$} \\
\hline & Normal & 55 & $66,3 \%$ & \\
\hline & Meningkat & 9 & $10,8 \%$ & \\
\hline & Tidak Diukur & 19 & $22,9 \%$ & \\
\hline \multirow[t]{3}{*}{2.} & Gula Darah Sewaktu (GDS) & & & \multirow[b]{3}{*}{$>200 \mathrm{mg} / \mathrm{dL}$} \\
\hline & Normal & 79 & $95,2 \%$ & \\
\hline & Tinggi & 4 & $4,8 \%$ & \\
\hline \multirow[t]{3}{*}{3.} & Kolesterol & & & \multirow[b]{3}{*}{$>200 \mathrm{mg} / \mathrm{dL}$} \\
\hline & Normal & 69 & $83,1 \%$ & \\
\hline & Tinggi & 14 & $16,9 \%$ & \\
\hline \multirow[t]{4}{*}{4.} & Asam urat & & & \multirow{4}{*}{$\begin{array}{l}\text { Laki-laki: }>7 \mathrm{mg} / \mathrm{dL} \\
\text { Perempuan: }>6 \mathrm{mg} / \mathrm{dL}\end{array}$} \\
\hline & Normal & 41 & $49,4 \%$ & \\
\hline & Tinggi & 21 & $25,3 \%$ & \\
\hline & Tidak Diukur & 21 & $25,3 \%$ & \\
\hline \multirow[t]{7}{*}{5.} & Status Gizi & & & \\
\hline & Kurang & 1 & $1,2 \%$ & \\
\hline & Normal & 14 & $16,9 \%$ & \\
\hline & Kelebihan berat badan & 11 & $13,3 \%$ & $23-24,9 \mathrm{~kg} / \mathrm{m}^{2}$ \\
\hline & Obesitas derajat 1 & 20 & $24,1 \%$ & $25-29,9 \mathrm{~kg} / \mathrm{m}^{2}$ \\
\hline & Obesitas derajat 2 & 21 & $25,3 \%$ & $\geq 30 \mathrm{~kg} / \mathrm{m}^{2}$ \\
\hline & Tidak diukur & 16 & $19,3 \%$ & \\
\hline
\end{tabular}

\section{KESIMPULAN DAN SARAN}

Edukasi mengenai modifikasi pola makan dan gaya hidup yang diberikan pada kegiatan ini menambah pengetahuan serta memperluas wawasan warga peserta mengenai PTM khususnya penyakit metabolik. Warga yang sudah diberikan edukasi pada kegiatan ini, diharapkan dapat menjadi agent of change dan menularkan pengetahuanya kepada keluarganya dan masyarakat yang lebih luas lagi. Hasil pemeriksaan menunjukkan bahwa faktor risiko terbanyak pada warga peserta yaitu berat badan berlebih hingga obesitas, oleh karena itu untuk selanjutnya dapat 
dilakukan penelitian atau kegiatan abdimas yang terfokus pada masalah berat badan berlebih pada masyarakat.

\section{Ucapan Terima Kasih}

Kami mengucapkan terima kasih yang sebesar-besarnya kepada pihak-pihak yang telah memfasilitsi dan membantu kelancaran kegiatan ini. Terima kasih kepada Direktorat Penelitian dan Pengabdian Kepada Masyarakat Universitas Tarumanagara untuk bantuan pendanaan kegiatan ini. Kami juga berterima kasih atas fasilitasi dan kerja sama yang baik dengan Bapak Lurah Tomang, kader serta warga di Kelurahan Tomang, sehingga kegiatan ini dapat berlangsung dengan baik dan lancar.

\section{REFERENSI}

Erwinanto, Santoso A, Putranto JNE, Tedjasukmana P, Sukmawan R, Suryawan R, et al. (2017). Panduan Tata Laksana Dislipidemia 2017. PERKI, Jakarta.

Ikatan Dokter Indonesia. (2014). Panduan Praktik Klinis Bagi Dokter di Fasilitas Pelayanan Kesehatan Primer. IDI, Jakarta.

Indonesian Society of Hypertension. (2019). Konsensus Penatalaksanaan Hipertensi 2019. InaSH, Jakarta.

Kementerian Kesehatan Republik Indonesia. (2011). Penyakit Tidak Menular (PTM) Penyebab Kematian Terbanyak di Indonesia. Diakses tanggal 30 Agustus 2019. Tersedia dari: http://www.depkes.go.id/article/view/1637/penyakit-tidak-menular-ptm-penyebabkematian-terbanyak-di-indonesia.html

Kementerian Kesehatan Republik Indonesia. (2016). Germas Wujudkan Indonesia Sehat. Diakses tanggal 29 Agustus 2019. Tersedia dari:

http://www.depkes.go.id/article/view/16111500002/germas-wujudkan-indonesiasehat.html

Kementerian Kesehatan Republik Indonesia. (2018). Hasil Utama Riskesdas 2018. Badan Penelitian dan Pengembangan Kesehatan, Jakarta. Diakses tanggal 12 Juli 2019. Tersedia dari:

http://www.depkes.go.id/resources/download/infoterkini/materi_rakorpop_2018/Hasil\%2 0Riskesdas\%202018.pdf.

Kementerian Kesehatan Republik Indonesia. (2018). Potret Sehat Indonesia dari Riskesdas 2018. Diakses tanggal 29 Agustus 2019. Tersedia dari:

http://www.depkes.go.id/article/view/18110200003/potret-sehat-indonesia-daririskesdas-2018.html

Perhimpunan Reumatologi Indonesia. (2018). Pedoman Diagnosis dan Pengelolaan Gout 2018. Perhimpunan Reumatologi Indonesia, Jakarta.

Soegondo. (2002). Penatalaksanaan Diabetes Mellitus Terpadu. Fakultas Kedokteran Universitas Indonesia, Jakarta.

Soelistijo SA, Novida H, Rudijanto A, Soewondo P, Suastika K, Manaf A, et al. (2015). Konsensus Pengelolaan dan Pencegahan Diabetes Melitus Tipe 2 Di Indonesia 2015. PB. PERKENI, Jakarta.

World Health Organization. (2018). Noncommunicable diseases (NCDs). Diakses tanggal 21 Desember 2018. Tersedia dari: http://www.who.int/mediacentre/factsheets/fs355/en/. 